\title{
ANALISIS PERSEPSIONAL KARYAWAN DALAM HUBUNGAN ANTARA MOTIVASI DAN LINGKUNGAN KERJA TERHADAP KINERJA KARYAWAN DI PG SOEDHONO KABUPATEN NGAWI
}

\author{
Anissa Linawati $^{(1)}$, Darsono $^{(2)}$, Eny Lestari $^{(3)}$ \\ (1) Mahasiswa Program Studi Agribisnis Fakultas Pertanian UNS \\ (2) Dosen Pembimbing Utama \\ (3) Dosen Pembimbing Pendamping \\ Program Studi Agribisnis, Fakultas Pertanian, Universitas Sebelas Maret \\ J1.Ir. Sutami No. 36 A Kentingan Surakarta 57126 Telp./Fax.(0271) 637457 \\ Email: anissa.linawati@gmail.com
}

\begin{abstract}
This study aims to determine the relationship between motivation on employee performance in PG Soedhono Ngawi Regency, understand the relationship work environment on employee performance in PG Soedhono Ngawi Regency, and to figure out the relationship between motivation and work environment on employee performance in PG Soedhono Ngawi Regency. This research was conducted in PTPN $X I$ work unit PG Soedhono Ngawi Regency. Technique of determining the location and population in this study is purposive sampling technique respondents using Slovin Formula where the number of samples are 76 employees. The techniques of collecting data are observation, interviews and recording. The basic analysis is descriptive analysis of the survey technique. The data analysis used Rank Spearman Correlation analysis. The results showed that motivation has a positive and significant relationship to employee performance in $P G$ Soedhono with weak strength criteria. The work environment has a negative relationship and no significant effect on the performance of employees in PG Soedhono criteria very weak force. While the motivation and the working environment has a positive correlation to the performance of employees in PG Soedhono with weak strength criteria.
\end{abstract}

Keywords: rank spearman correlation analysis, employee, employee performance, work environment, motivation

\begin{abstract}
Abstrak: Penelitian ini bertujuan untuk mengetahui hubungan motivasi terhadap kinerja karyawan di PG Soedhono Kabupaten Ngawi, mengetahui hubungan lingkungan kerja terhadap kinerja karyawan di PG Soedhono Kabupaten Ngawi, serta mengetahui hubungan motivasi dan lingkungan kerja terhadap kinerja karyawan di PG Soedhono Kabupaten Ngawi. Penelitian ini dilaksanakan di PTPN XI unit kerja PG Soedhono Kabupaten Ngawi. Teknik penentuan lokasi dan populasi pada penelitian ini dilakukan secara purposive dengan teknik pengambilan sampel responden menggunakan Formula Slovin dimana jumlah sampel sebanyak 76 karyawan. Teknik pengumpulan data melalui observasi, wawancara dan pencatatan. Analisis dasar yang digunakan adalah deskriptif analisis dengan teknik survey. Analisis data yang digunakan dengan analisis Korelasi Rank Spearman. Hasil penelitian menunjukkan bahwa motivasi memiliki hubungan yang positif dan signifikan terhadap kinerja karyawan di PG Soedhono dengan kriteria kekuatan yang lemah. Lingkungan kerja memiliki hubungan yang negatif dan tidak signifikan terhadap kinerja karyawan di PG Soedhono dengan kriteria kekuatan yang sangat lemah. Sedangkan motivasi dan lingkungan kerja memiliki hubungan positif yang signifikan terhadap kinerja karyawan di PG Soedhono dengan kriteria kekuatan yang lemah.
\end{abstract}


Kata kunci: analisis korelasi rank spearman, karyawan, kinerja karyawan, lingkungan kerja, motivasi

\section{PENDAHULUAN}

Produksi merupakan pusat pelaksanaan kegiatan yang konkrit bagi pengadaan barang dan jasa pada suatu badan usaha dan perusahaan. Proses produksi tersebut merupakan bagian yang terpenting dalam perusahaan, karena apabila berhenti maka perusahaan akan mengalami kerugian. Pada kegiatan produksi faktor tenaga kerja (karyawan) mempunyai pengaruh besar, karena tenaga kerjalah yang melaksanakan proses produksi tersebut.

Salah satu faktor yang dapat digunakan perusahaan dalam mempengaruhi perilaku karyawan untuk bekerja lebih giat dalam rangka menjaga eksistensi dan memajukan perusahaan adalah faktor motivasi. Motivasi adalah seperangkat dorongan baik yang berasal dari dalam maupun dari luar diri seseorang yang paling tidak sebagian turut menghasilkan tindakan produktif tertentu (Devung, 1989). Adanya motivasi tersebut, dapat merangsang karyawan untuk lebih menggerakan tenaga dan pikiran dalam merealisasikan tujuan perusahaan. Apabila kebutuhan akan hal ini terpenuhi maka akan timbul kepuasan dan kelancaran terhadap peningkatan kinerja karyawan.

Selain itu, situasi dan kondisi lingkungan kerja juga berpengaruh terhadap tingkat kinerja yang dicapai seseorang. Lingkungan kerja dalam suatu perusahaan sangat penting untuk diperhatikan oleh manajemen. Lingkungan kerja adalah segala sesuatu yang ada di sekitar para pekerja yang dapat mempengaruhi dirinya dalam melaksanakan tugas-tugas yang diemban (Nitisemito, 1996). Oleh karena itu, hendaknya diusahakan agar lingkungan kerja harus baik dan kondusif karena mampu membuat karyawan merasa nyaman berada di ruangan dan merasa senang serta bersemangat untuk melaksanakan tugas-tugasnya sehingga kepuasan kerja akan terbentuk dan dari kepuasan kerja karyawan tersebut maka kinerja karyawan juga akan meningkat.

PG Soedhono merupakan satu-satunya pabrik gula yang ada di Kabupaten Ngawi sebagai penampung hasil perkebunan tebu masyarakat petani tebu daerah Ngawi dan sekitarnya. Sebagian besar karyawan yang bekerja disana merupakan masyarakat sekitar perusahaan dengan tingkat pendidikan yang sedang, dan bahkan ada pula yang memiliki tingkat pendidikan yang rendah. Kondisi kesehatan karyawan juga menurun ketika musim giling tiba menurut beberapa karyawan. Selain itu, ada beberapa karyawan yang merasakan bosan ketika bekerja serta tingkat kehadiran karyawan juga cukup rendah, dimana banyak karyawan yang tidak masuk kerja tanpa ijin yang jelas menurut beberapa kepala bagian.

Motivasi kerja yang tinggi akan mempengaruhi kinerja karyawan untuk bekerja dengan baik. Lingkungan kerja yang kondusif juga perlu diperhatikan agar karyawan merasa nyaman dalam bekerja yang akan berdampak pada kinerja karyawan. Hal ini sesuai dengan pendapat Ernes J. McCormick dalam (1985) mendefinisikan motivasi kerja dalam hubungannya dengan lingkungan kerja sebagai kondisi yang berpengaruh membangkitkan, mengarahkan, dan memelihara perilaku yang berhubungan dengan kinerja.

Dilihat pada kondisi tersebut, maka penting bagi pihak perusahaan untuk dapat memperoleh laba yang sebanyak-banyaknya dengan meningkatkan kinerja karyawan mereka. Kinerja karyawan perusahaan dapat dicapai sesuai harapan dengan motivasi karyawan yang tinggi dalam bekerja dan dorongan lingkungan kerja yang mendukung agar dapat berproduksi dengan optimal. Bertolak dari pemikiran tersebut, maka diperlukan adanya penelitian mengenai "Analisis Persepsional Karyawan dalam Hubungan antara Motivasi dan Lingkungan Kerja terhadap Kinerja Karyawan di PG Soedhono Kabupaten Ngawi”.

\section{METODE PENELITIAN}

Metode dasar penelitian yang digunakan adalah metode deskriptif analisis. Menurut Nazir (1988), penelitian deskriptif analitis bertujuan untuk membuat deskripsi secara sistematis, faktual, dan akurat mengenai fakta-fakta, sifatsifat serta hubungan fenomena yang diselidiki. Teknik pelaksanaan dalam penelitian ini adalah teknik penelitian survey. Menurut Singarimbun 
dan Effendi (1995) adalah penelitian survey merupakan penelitian yang mengambil sampel dari suatu populasi dan menggunkan kuisioner sebagai alat pengumpulan data yang pokok.

Metode penentuan lokasi penelitian dilakukan secara purposive (sengaja), yaitu cara pengambilan daerah penelitian secara sengaja dengan mempertimbangkan alasan tertentu sesuai dengan tujuan penelitian (Singarimbun dan Efendi, 1995). Penelitian ini dilaksanakan di PTPN XI unit kerja PG Soedhono Kabupaten Ngawi pada bulan Juni 2016 dengan pertimbangan perusahaan ini merupakan salah satu perusahaan BUMN penyumbang produsen gula di Indonesia dan satu-satunya yang ada di Kabupaten Ngawi yang menampung hasil tebu rakyat sekitar kabupaten Ngawi. Karyawan PG Soedhono mayoritas memiliki tingkat pendidikan sedang, tingkat kehadiran kurang, tingkat kebosanan tinggi, dan kondisi kesehatan karyawan menurun ketika musim giling tiba.

Populasi yang diambil adalah karyawan seluruh bagian dengan data karyawan bulan Mei 2016 sebanyak 320 karyawan. Teknik penentuan sampel menggunakan Formula Slovin (Riduwan, 2005) dan didapatkan sebanyak 76 sampel responden. Penentuan sampel karyawan harian lepas ini menggunakan metode Proportional Random Sampling yaitu pengambilan sampel berdasarkan perbandingan besar kecilnya dari sub-sub populasi dan diambil secara random. Data yang digunakan meliputi data primer yang didapatkan secara langsung dari responden dan sekunder yang didapatkan dari data perusahaan serta kepustakaan yang terkait. Metode analisis data dengan analisis deskriptif dan skala Likert.

Uji instrumen penelitian dilakukan dengan uji validitas konstruk meggunakan teknik korelasi product moment. Menurut Ghozali (2005), Uji signifikansi dilakukan membandingkan nilai $r$ hitung dengan $r$ tabel. Jika $r$ hitung lebih besar dari $r$ tabel dan nilai positif, maka butir atau pertanyaan atau indikator tersebut dinyatakan valid. Uji reabilitas dengan teknik Alpha Cronbach. Kriteria suatu instrument penelitian dikatakan reliable dengan menggunakan teknik Alpha Cronbach bila koefisien reliabilitas $\left(\mathrm{r}_{11}\right)>0,6$. Variabel bebas terdiri dari motivasi dan lingkungan kerja. Variabel terikatnya yaitu kinerja karyawan.
Pengukuran tingkat motivasi, tingkat kenyamanan lingkungan kerja, dan tingkat kinerja karyawan di PG Soedhono menggunakan Lebar Interval.

$$
\begin{aligned}
& \mathrm{I}=\left(\frac{\sum \text { Nilai Tertinggi }-\sum \text { Nilai Terendah }}{}\right) \\
& \text { Kekuatan hubungan antara motivasi dan }
\end{aligned}
$$
lingkungan kerja terhadap kinerja karyawan, dapat diketahui dengan menggunakan Teknik Analisis Korelasi Rank Spearman $\left(r_{s}\right)$. Koefisien korelasi adalah nilai yang menunjukan kuat/tidaknya hubungan linier antar dua variabel (Siegel, 1997).

$$
r_{s}=1-\frac{6 \sum d_{i}^{2}}{n\left(n^{2}-1\right)}
$$

Tingkat signifikansi Hubungan Motivasi dan Lingkungan Kerja terhadap Kinerja Karyawan di PG Soedhono digunakan rumus:

$$
t=r_{s} \sqrt{\frac{N-2}{1-r_{s}^{2}}}
$$

Kriterianya adalah apabila $\mathrm{t}$ hitung $\geq \mathrm{t}$ tabel $(\alpha$ $=0,01)$, maka $\mathrm{H}_{0}$ ditolak dan $\mathrm{H}_{1}$ diterima. Berarti ada hubungan positif yang signifikan antara motivasi dan lingkungan kerja terhadap kinerja karyawan di PG Soedhono kabupaten Ngawi. Begitu pula sebaliknya.

Keeratan atau kekuatan hubungan antar variabel, dapat ditunjukkan melalui nilai koefisien korelasi. Berikut adalah tabel makna nilai korelasi yang dapat dijadikan pedoman untuk memberikan interpretasi koefisien korelasi Rank Spearman menurut Sugiyono (2007), yaitu:

Tabel 1. Tabel Pedoman Interpretasi Tingkat Koefisien Korelasi

\begin{tabular}{ccll}
\hline & $\begin{array}{c}\text { Nilai Koefisien } \\
\text { Ko. }\end{array}$ & $\begin{array}{l}\text { Makna Kategori Kekuatan } \\
\text { Hubungan }\end{array}$ \\
\hline 1 & 0,00 & $-0,199$ & Hubungan yang Sangat Lemah \\
2 & $0,20-0,399$ & Hubungan yang Lemah \\
3 & $0,40-0,599$ & Hubungan yang Sedang \\
4 & $0,60-0,799$ & Hubungan yang Kuat \\
5 & $0,80-1,000$ & Hubungan yang Sangat Kuat \\
\hline
\end{tabular}

Sumber: Sugiyono, 2007 


\section{HASIL DAN PEMBAHASAN}

\section{Kondisi Umum Lokasi Penelitian}

PG Soedhono didirikan pada tahun 1888 oleh perusahaan Verenigde Vorsendsche Cultural Maatschaapy (VVCM) dan pada tanggal 11 Maret 1996 resmi menjadi anak perusahaan dibawah naungan PTP Nusantara XI (Persero) dengan alamat direksi di Jl. Merak no 1 Surabaya. PG Soedhono terletak di Desa Tepas, Kecamatan Geneng, Kabupaten Ngawi. Batasbatas PG Soedhono adalah sebelah utara berbatasan dengan desa Tempuran, sebelah selatan berbatasan dengan desa Tambakromo, sebelah timur berbatasan dengan desa Sambirobyong, dan sebelah barat berbatasan dengan desa Satrean. Luas tanah dan bangunan pabrik kurang lebih $5000 \mathrm{~m} 2$ terdiri dari luas bangunan industri dan fasilitas lain sebesar $3500 \mathrm{~m} 2$ dan luas tanah yang tidak tertutup sebesar $1500 \mathrm{~m} 2$. PG Soedhono selain menghasilkan gula pasir sebagai hasil utama juga menghasilkan hasil sampingan berupa tetes tebu, ampas tebu, blotong, dan abu ketel.

Uji Instrumen Validitas motivasi didapatkan 10 item dinyatakan tidak valid dan 14 item dinyatakan valid dari 24 item pernyataan. Uji Instrumen Validitas lingkungan kerja didapatkan dinyatakan tidak valid dan 10 item dinyatakan valid dari 15 item pernyataan. Uji Instrumen Validitas kinerja karyawan didapatkan 10 item dinyatakan tidak valid dan 8 item dinyatakan valid dari 18 item pernyataan. Hasil uji Reliabilitas diperoleh Cronbach's Alpha kuesioner motivasi kerja sebesar 0,789 dan kuesioner lingkungan kerja sebesar 0,819 serta kuesioner kinerja karyawan sebesar 0,720 .

\section{Karakteristik Responden Jenis Kelamin}

Jenis kelamin merupakan salah satu karakteristik yang sangat berpengaruh terhadap operasional suatu perusahaan. Sebagian besar responden yang bekerja di PG Soedhono adalah laki-laki, yakni dengan jumlah responden sebanyak 69 orang dengan presentase 90,79\%, sedangkan jumlah responden perempuan adalah 7 orang dengan presentase hanya sebesar $9,21 \%$. Perbedaan yang cukup banyak antara responden laki-laki dan perempuan pada PG Soedhono yaitu dengan selisih sebesar $81,58 \%$. Hal ini dikarenakan jenis pekerjaan pada setiap bagian yang ada di PG Soedhono dilakukan cukup berat dan butuh keahlian laki-laki, seperti bagian teknik instalasi, kendaraan, pengolahan, tanaman, loko/remise, railban, dan quality control. Sedangkan karyawan perempuan lebih banyak kepada bagian Administrasi, Keuangan, dan Umum yang tidak terlalu berat dan membutuhkan kejelian juga ketelitian. Oleh karena itu jumlah karyawan laki-laki lebih banyak dibandingkan dengan jumlah karyawan perempuan.

\section{Usia}

Usia (umur) adalah lama waktu hidup atau ada (sejak dilahirkan atau diadakan). Usia karyawan yang bekerja pada PG Soedhono yang menjadi responden dalam penelitian ini merupakan golongan usia produktif yang berkisar antara umur 21-60 tahun. Karyawan dengan rentan usia 41-50 tahun masih mendominasi kerja karyawan di PG Soedhono. Sedangkan karyawan dengan rentan usia 21-30 tahun masih menjadi usia yang paling rendah yang bekerja di PG Sodhono. Maka dari itu, dapat dikatakan sebagian besar karyawan yang bekerja pada PG Soedhono merupakan karyawan yang sudah memiliki pengalaman kerja yang cukup banyak dan seharusnya mampu mengembangkan kreativitasnya dalam melakukan pekerjaannya. Sehingga mampu meningkatkan kinerja mereka dalam mengambangkan perusahaan.

\section{Tingkat Pendidikan}

Tingkat pendidikan akan mempengaruhi nilainilai yang dianut seseorang, cara berfikir, cara pandang bahkan persepsinya terhadap suatu masalah (Sumarwan, 2003). Sebagian besar karyawan yang bekerja pada PG Soedhono berpendidikan sedang (SMA) yaitu dengan jumlah 53 orang responden dengan presentase $69,73 \%$. Karyawan yang bekerja pada PG Soedhono banyak yang tidak memiliki tingkat pendidikan yang tinggi, dikarenakan perusahaan lebih banyak mengambil karyawan sekitar perusahaan. Selain itu, perusahaan memilih untuk memperkerjakan karyawan dengan pendidikan sedang dikarenakan sebagai bentuk CSR atau pengabdian perusahaan terhadap masyarakat sekitar perusahaan dan perusahaan juga merasa dapat beroperasi dengan baik dengan karyawan-karyawan yang memiliki tingkat pendidikan sedang. Namun, 
untuk karyawan dengan posisi jabatan yang tinggi dan cukup penting, memiliki tingkat pendidikan minimal S1 seperti halnya Manajer dan Asisten Manajer perusahaan. Selain itu, untuk karyawan yang bekerja pada bidang Administrasi, Keuangan, dan Umum juga banyak yang memiliki pendidikan tinggi karena bidang tersebut membutuhkan seorang yang ahli untuk mengelolanya.

\section{Masa Kerja}

Sebagian besar responden dalam penelitian ini berada pada klasifikasi masa kerja 1-10 tahun dengan presentase sebesar 39,47\%. Karyawan PG Soedhono sebagian besar memiliki masa kerja yang baru sebentar. Hal ini karena banyak karyawan yang berusia lanjut dan sudah pensiun, sehingga digantikan dengan karyawan-karyawan masih berusia muda. Sedangkan responden penelitian yang memiliki masa kerja >30 tahun, ada sebanyak 9,21\% yang rata-rata sudah akan pensiun. Semakin lama seorang karyawan bekerja pada sebuah perusahaan akan mempermudah karyawan tersebut dalam melakukan pekerjaan karena ilmu dan pengalaman mereka sudah cukup banyak terhadap perusahaan.

\section{Deskripsi Variabel Penelitian Motivasi}

Besar distribusi variabel motivasi terhadap kinerja karyawan PG Soedhono dari 76 karyawan adalah sebesar $65,8 \%$. Prosentase ini berada pada kategori tinggi yaitu tingkat motivasi karyawan yang sangat tinggi dengan jumlah responden sebesar 50 karyawan. Sedangkan sisanya $31,6 \%$ responden berada pada kategori tinggi dengan jumlah responden sebanyak 24 karyawan, dan $2,6 \%$ responden berada pada kategori cukup dengan jumlah responden sebanyak 2 karyawan.

\section{Lingkungan Kerja}

Besar distribusi variabel lingkungan kerja terhadap kinerja karyawan PG Soedhono adalah 9,2\% memiliki kategori sangat nyaman dengan jumlah responden sebesar 7 karyawan. Sedangkan sisanya $65,8 \%$ responden berada pada kategori nyaman dengan jumlah responden sebanyak 50 karyawan, dan $25 \%$ responden berada pada kategori cukup nyaman dengan jumlah responden sebanyak 19 karyawan.

\section{Kinerja Karyawan}

Besar distribusi variabel kinerja karyawan PG Soedhono adalah 51,3 \% memiliki kategori sangat baik dengan jumlah responden sebanyak 39 karyawan. Sedangkan sisanya 47,3 \% responden berada pada kategori baik dengan jumlah responden sebanyak 36 karyawan, dan $1,3 \%$ responden berada pada kategori cukup baik dengan jumlah responden sebanyak 1 karyawan.

\section{Hubungan Motivasi dan Kinerja Karyawan PG Soedhono Kabupaten Ngawi}

Berdasarkan Tabel 2, dapat diketahui bahwa nilai koefisien korelasi $\left(r_{s}\right)$ antara motivasi terhadap kinerja karyawan pada $\alpha=0,01$ yaitu sebesar 0,388. Artinya kekuatan korelasi antara variabel motivasi terhadap kinerja karyawan ialah sebesar 0,388 atau memiliki kriteria kekuatan hubungan yang positif dengan kategori lemah. Sedangkan untuk nilai t hitung diketahui sebesar 3,579 dimana lebih besar dari $\mathrm{t}$ tabel sebesar 2,379 pada tingkat kepercayaan $99 \%$. Hal ini berarti terdapat hubungan yang signifikan antara motivasi terhadap kinerja karyawan.

Tabel 2. Hasil Uji Statistik Hubungan Motivasi terhadap Kinerja Karyawan

\begin{tabular}{cccc}
\hline \multirow{2}{*}{ Variabel } & \multicolumn{2}{c}{$\begin{array}{c}\text { Kinerja Karyawan } \\
(\mathrm{Y})\end{array}$} & \multirow{2}{*}{ Keterangan } \\
\cline { 2 - 3 } & $r_{s}$ & t hit & \\
\hline $\begin{array}{c}\text { Motivasi } \\
(\mathrm{X} 1)\end{array}$ & $0,388^{* *}$ & 3,597 & Signifikan \\
\hline
\end{tabular}

Sumber : Analisis Data Primer, 2016

Keterangan:

$r_{s} \quad:$ Koefisien Korelasi Rank Spearman

T tabel : 2,379 pada $\alpha=0,01$ (one-tailed)

Menurut Hasibuan (2013) motivasi sangatlah penting bagi seorang karyawan karena motivasi merupakan suatu hal yang dapat menyebabkan seseorang agar mau bekerja lebih giat dalam mencapai hasil yang optimal. Menurut Gardjito Musadieq dan Nurtjahjono(2014) kinerja karyawan diartikan sebagai pencapaian tugas, dimana karyawan dalam bekerja harus sesuai dengan program kerja organisasi untuk menunjukkan tingkat kinerja organisasi dalam mencapai visi, misi, dan tujuan organisasi. 
Mayoritas karyawan di PG Soedhono merasa kebutuhan utama mereka sudah tercukupi dengan jumlah gaji yang mereka terima, sehingga pada indikator kebutuhan fisiologis, motivasi karyawan yang tinggi sudah dapat tercapai. Indikator lain yaitu kebutuhan akan rasa aman yang ada pada karyawan yang sudah dapat dikatakan sudah tercapai dengan baik. Kebutuhan akan rasa aman tidak hanya menyangkut keamanan fisik di segala tempat dan segala keadaan saja, tetapi juga keamanan mental psikologis dalam menghadapi setiap kondisi, jaminan atau perlindungan dari yang membahayakan kelangsungan hidup dan kehidupan dalam segala aspeknya. Selanjutnya adalah kebutuhan sosial karyawan baik di dalam maupun di luar perusahaan yang mereka butuhkan juga sudah terpenuhi dengan baik. Keinginan karyawan untuk memperoleh penghargaan, sudah merasa cukup dengan dihormati masyarakat sekitar atas pekerjaan yang dilakukannya. Karyawan juga merasa bahwa bekerja di PG Soedhono perusahaan sudah bisa memberikan penghargaan prestasi, sehingga motivasi karyawan tinggi sudah dapat tercapai. Namun, hampir semua karyawan ingin memiliki posisi penting dalam perusahaan, sehingga karyawan akan bekerja lebih giat agar dapat memiliki posisi penting perusahaan sehingga karyawan menjadi lebih termotivasi.

\section{Hubungan Lingkungan Kerja dan Kinerja} Karyawan PG Soedhono Kabupaten Ngawi

Tabel 3. Hasil Uji Statistik Hubungan Lingkungan Kerja terhadap Kinerja Karyawan

\begin{tabular}{cccc}
\hline \multirow{2}{*}{ Variabel } & \multicolumn{2}{c}{ Kinerja Karyawan } & \\
\cline { 2 - 3 } & $r_{s}$ & t hit & Keterangan \\
\hline $\begin{array}{c}\text { Lingkungan } \\
\text { Kerja (X2) }\end{array}$ & $-0,019$ & $-0,162$ & $\begin{array}{c}\text { Tidak } \\
\text { Signifikan }\end{array}$ \\
\hline
\end{tabular}

Sumber : Analisis Data Primer, 2016

Keterangan:

$r_{s} \quad$ : Koefisien Korelasi Rank Spearman

T tabel : 2,379 pada $\alpha=0,01$ (one-tailed)

Berdasarkan Tabel 3, dapat diketahui bahwa nilai koefisien korelasi $\left(r_{s}\right)$ antara lingkungan kerja terhadap kinerja karyawan pada $\alpha=0,01$ yaitu sebesar $-0,019$. Artinya kekuatan korelasi antara variabel lingkungan kerja terhadap kinerja karyawan ialah sebesar
-0,019 dimana nilai $r_{s}$ berhubungan negatif atau berlawanan arah dengan kriteria kekuatan hubungan yang sangat lemah. Sedangkan untuk nilai $t$ hitung diketahui sebesar -0,162 dimana lebih kecil dari t tabel sebesar 2,379 pada tingkat kepercayaan 99\%. Hal ini berarti terdapat hubungan yang tidak signifikan antara lingkungan kerja terhadap kinerja karyawan. Ini artinya lingkungan kerja yang ada di PG Soedhono memiliki hubungan yang lemah dan tidak signifikan dengan tingkat kinerja karyawan.

Menurut Mangkunegara (2005), lingkungan kerja mempunyai hubungan yang sangat erat terhadap kinerja karyawan. Menurut Bambang Guritno dan Waridin (2005) kinerja merupakan perbandingan hasil kerja yang dicapai oleh karyawan dengan standar yang telah ditentukan.

Hal ini sesuai juga menurut Mangkunegara (2005), lingkungan kerja mempunyai hubungan yang sangat erat terhadap kinerja karyawan, motif berprestasi yang perlu dimiliki oleh karyawan harus ditumbuhkan dari dalam diri sendiri dan dari lingkungan kerja, karena motif berprestasi yang ditumbuhkan dari dalam diri sendiri akan membentuk suatu kekuatan diri dan jika situasi lingkungan kerja turut menunjang maka pencapaian kinerja akan lebih mudah.

Kondisi lingkungan kerja yang ada di PG Soedhono berhubungan lemah dan berlawanan arah dengan kinerja karyawan. Gambaran kondisi lingkungan kerja karyawan di perusahaan bisa dikatakan cukup baik namun banyak hal juga yang masih memiliki kekurangan, seperti halnya adalah keadaan pencahayaan, sirkulasi udara, kebisingan, bau tidak sedap di beberapa ruangan yang masih buruk. Hal ini menyebabkan karyawan terkadang juga merasa tidak nyaman ketika bekerja. Sehingga hal ini mempengaruhi kinerja karyawan yang menyebabkan penurunan kinerja. Selain kondisi lingkungan kerja yang buruk, hal ini juga diperparah dengan adanya kondisi ketika musim giling tiba dengan beberapa bentuk gangguan yang mengganggu konsentrasi karyawan ketika bekerja. 
Hubungan Motivasi dan Lingkungan Kerja terhadap Kinerja Karyawan PG Soedhono Kabupaten Ngawi

Tabel 4. Hasil Uji Statistik Hubungan Motivasi dan Lingkungan Kerja terhadap Kinerja Karyawan

\begin{tabular}{llll}
\hline & \multicolumn{2}{c}{ Kinerja Karyawan (Y) } & \\
\cline { 2 - 3 } \multicolumn{1}{c}{ Variabel } & $r_{s}$ & $\mathrm{t}$ hit & Keterangan \\
\hline Motivasi dan & & & \\
Lingkungan & & & \\
Kerja & & & \\
$(\mathrm{X} 1$ dan $\mathrm{X} 2)$ & $0,364^{* *}$ & 3,339 & Signifikan \\
\hline
\end{tabular}

Sumber : Analisis Data Primer, 2016

Keterangan:

$r_{s} \quad$ : Koefisien Korelasi Rank Spearman

T tabel : 2,379 pada $\alpha=0,01$ (one-tailed)

Berdasarkan Tabel 4, dapat diketahui bahwa nilai koefisien korelasi $\left(r_{s}\right)$ antara motivasi dan lingkungan kerja terhadap kinerja karyawan pada $\alpha=0,01$ yaitu sebesar 0,364 . Artinya besar korelasi antara variabel motivasi dan lingkungan kerja terhadap kinerja karyawan ialah sebesar 0,364 atau memiliki hubungan positif dengan kriteria kekuatan hubungan kategori lemah. Sedangkan untuk nilai t hitung diketahui sebesar 3,339 dimana lebih besar dari $\mathrm{t}$ tabel sebesar 2,379 pada tingkat kepercayaan 99\%. Ini artinya motivasi dan lingkungan kerja yang ada di PG Soedhono memiliki hubungan yang yang signifikan dengan tingkat kinerja karyawan.

Menurut Mathis \& Jakson (2007), kinerja karyawan adalah apa yang dilakukan dan tidak dilakukan oleh karyawan.

Faktor motivasi dan lingkungan kerja belum seluruhnya menjadi perhatian utama dari para karyawan dan juga manajer di PG Soedhono. Hal ini terbukti dari hasil survey wawancara di lapangan dimana ada beberapa karyawan yang hanya bekerja untuk dapat memenuhi kebutuhan fisiologis dan kebutuhan akan rasa aman saja. Beberapa karyawan belum bisa mencapai tingkat tertinggi hierarki kebutuhan manusia dalam bekerja. Hanya beberapa karyawan yang memiliki jabatan penting perusahaan yang sudah mencapainya. Selain itu, lingkungan kerja yang kurang memadai menjadi satu hal juga yang dikeluhkan oleh para karyawan dengan fasilitas yang seadanya dari pemerintah terhadap perusahaan yang notabene adalah perusahaan BUMN.

Supardi (2003), menyatakan lingkungan kerja memegang peranan penting terhadap baik buruknya kualitas hasil kinerja karyawan. Menurut Ernes J. McCormick (1985) mendefinisikan motivasi kerja dalam hubungannya dengan lingkungan kerja sebagai kondisi yang berpengaruh membangkitkan, mengarahkan, dan memelihara perilaku yang berhubungan dengan kinerja.

Lingkungan kerja fisik di PG Soedhono sudah cukup baik, hanya saja beberapa ruangan kerja masih kurang terbuka terhadap masuknya cahaya matahari dan sirkulasi udara yang terjadi menjadi kurang baik. Selain itu, jarak antara kantor dengan jalan raya yang cukup dekat, serta jarak antara kantor dengan tempat yang digunakan untuk proses produksi yang cukup dekat. Hal ini menyebabkan kondisi kantor menjadi bising karena terkena dampak dari suara mesin kendaraan dan suara mesin pabrik baik yang diperbaiki maupun mesin pabrik yang sedang beroperasi.

Selain itu, ruangan yang digunakan untuk para Pjs. Manajer Bagian dan karyawan yang sangat sempit dan berada di dalam bangunan pabrik membuat kondisi ini tidak efektif bagi manajer dan karyawan ketika bekerja, terutama untuk ruangan Bagian Pengolahan. Hal ini menyebabkan kinerja karyawan yang kurang efektif dan konsentrasi karyawan dapat terganggu. Lingkungan kerja nonfisik merupakan hal yang juga memerlukan perhatian yang khusus, karena apabila hubungan yang terjalin antar karyawan tidak baik, akan mempengaruhi karyawan dalam bekerja. Selain itu akan timbul persaingan yang tidak sehat dan saling menjatuhkan antar karyawan. Hal tersebut sering terjadi pada setiap perusahaan, tergantung bagaimana para manajer menyikapi hal tersebut.

\section{KESIMPULAN DAN SARAN}

Berdasarkan hasil penelitian tentang hubungan motivasi dan lingkungan kerja terhadap kinerja karyawan di PG Soedhono dapat diambil kesimpulan sebagai berikut : 1). Motivasi karyawan berkorelasi positif dan signifikan terhadap kinerja karyawan PG Soedhono. 2). Motivasi karyawan dan lingkungan kerja 
berkorelasi positif dan signifikan terhadap kinerja karyawan PG Soedhono.

Adapun saran-saran yang dapat disampaikan dalam penelitian ini adalah kepada PG Soedhono, pemberian motivasi kerja kepada seluruh karyawan perlu ditingkatkan, mengingat hasil analisis hubungan antara motivasi dan kinerja karyawan masih memiliki hubungan yang lemah. Peningkatan motivasi dapat dilakukan dengan menciptakan suasana kerja yang positif, nyaman, dan menyenangkan, serta pemberian dukungan kerja, apresiasi, pengakuan, dan promosi jabatan secara kontinyu kepada karyawan yang memiliki prestasi kerja seperti hasil yang melebihi target dan kualitas hasil yang didapat sangat baik. Sehingga, dalam hal ini devisi pengembangan sumber daya manusia atau HRD memiliki peranan vital terutama dalam hal pemeliharaan dan peningkatan motivasi kerja karyawan.

\section{DAFTAR PUSTAKA}

Devung, Simon. 1989. Pengantar Ilmu Administrasi Dan Manajemen. Depdikbud. Jakarta.

Ernest J. McCormick. 1985. Indutrial Psycology. Prentice Hall, Inc. New York.

Ghozali, Imam. 2005. Aplikasi Analisis Multivariate Dengan Program Spss. Badan Penerbit Universitas Diponegoro. Semarang.

Guritno, Bambang dan Waridin. 2005. Pengaruh Persepsi Karyawan Mengenai Perilaku Kepemimpinan, Kepuasan Kerja Dan Motivasi Terhadap Kinerja. Jrbi. Vol 1. No 1. Hal: 63-74.
Hasibuan, Sp. Malayu. 2007. Manajemen Sumber Daya Manusia. Cetakan Keenam. Edisi Revisi. Bumi Aksara. Jakarta.

Mangkunegara, Anwar Prabu. 2005. Manajemen Sumber Daya Perusahaan. PT. Remaja Rosda Karya. Bandung.

Mathis, Robert L. dan Jackson. John H. 2007. Human Resource Management (Manajemen Sumber Daya Manusia). Edisi 10. Salemba Empat. Jakarta.

Nazir, M. 2003. Metode Penelitian. Ghalia Indonesia. Jakarta.

Nitisemito, Alex S. 1996. Manajemen Sumber Daya Manusia. Cetakan Sembilan. Edisi Ketiga. Ghalia Indonesia. Jakarta.

Riduwan. 2005. Belajar Mudah Penelitian Untuk Guru Karyawan Dan Peneliti Pemula. Alfabeta. Bandung.

Siegel, Sidney. 1997. Metode Stasistika NonParametris. Gramedia Pustaka Utama. Jakarta.

Singarimbun, Masri Dan Sofian Efendi. 1995. Metode Penelitian Survei. Lp3es. Jakarta.

Sugiyono. 2007. Statistika Untuk Penelitian. CV. Alfabeta. Bandung.

Sumarwan, U. 2003. Perilaku Konsumen Teori dan Penerapannya dalam Pemasaran. Ghalia Indonesia. Jakarta.

Supardi. 2003. Kinerja Karyawan. Ghalia Indonesia. Jakarta. 